\title{
学会における託児所運営の意義とプライマリ・ケア関連 領域における設置の流れ
}

\begin{abstract}
Meaning of day nursery management at academic society and flow of installation in the area related to primary care
\end{abstract}

\section{男女共同参画委員会 村田亜紀子*1,2 西 村 真 紀 $^{* 1,3}$}

The committee for gender equality of Japan Primary Care Association

Akiko Murata $^{* 1,2}$, Maki Nishimura*1,3

\begin{abstract}
要 旨
託児所の設置は, 女性医師が働き続けやすい環境整備のためのポジティブ・アクションの手法の 1 つである. プライマリ・ケア関連領域では, 21 世紀初頭, ニーズ調査や複数の当事者によるベビーシッター確保を契機 に個別の学術大会・セミナー単位で託児所の設置が開始された. 3 学会の合併により日本プライマリ・ケア連 合学会が設立し，2013 年学会本部からの託児委託費の助成・男女共同参画委員会による託児所設置支援が開 始した後より託児所充実へ向けた取組みが着実に進み, 2015 年度現在, 学術大会 (懇親会含む), 学会主催の 4 セミナー（春季・夏期・秋季 · 冬期）と 1 回の指導医養成講習会に託児所を設置している. 託児所の設置と プライマリ・ケア関連領域 3 学会の設立から合併, 現在に至るまでの流れ・学会員数等推移を照らし合わせて 歴史を振り返る機会としたい.
\end{abstract}

Keywords : 男女共同参画 (gender equality), 女性医師 (female physicians), キャリア (career), 託児所 (nursery), 学会 (academic society)

\section{はじめに}

日本医学会分科会では, 専門医・認定医の資格取得 や維持に学術集会への参加を要することが多い。しか し, 学会託児所の設置のない場合は, 育児中の女性医 師の学術集会への参加が難しいことがある。これは, 女性医師の專門医・認定医取得が男性医師に比べて低 い原因の一つとして指摘されている1).

日本プライマリ・ケア連合学会 (以下 JPCA と略 す）の家庭医療専門医制度では, 家庭医療専門医/プ ライマリ・ケア認定医の更新申請に必要な生涯学習単 位 50 単位のうち, 年次学術集会や本学会が主催また は共催する生涯教育セミナー等での生涯教育単位 10 単位以上の取得が必須とされる ${ }^{23)}$. 現在, JPCA では 単位取得たけけでなく育児中等の医師の生涯教育支援を 目的に, 学術集会・春季・秋季生涯教育セミナー・若 手医師のための家庭医療学冬期セミナー（以下冬期セ ミナーと略す）で託児所設置を実施している。また， 講師お」び育児中の医学生支援の目的で, 2013 年度
より学生・研修医のための家庭医療学夏期セミナー (以下夏期セミナーと略す）での託児所設置を実施し ている.

今回, 男女共同参画委員会の託児所運営支援活動に 対し学会員の理解と支援を得る目的で, 医学界並びに 当学会の託児所設置（学術大会・セミナー等）の歴史 的経緯について，3学会合併前後の歴史を含めて概説 する.

\section{1. 日本医学会分科会における託児所設置の意義 と男女共同参画に関する動き}

近年, 医師における女性の割合は $19.7 \%$ にび, 29 歳以下で $35.5 \%, 30-34$ 歳で $32.2 \%$ と特に 30 代前 半までの比較的若い世代の女性医師比率が高まってい る $(2012 \text { 年 } 12 \text { 月 } 31 \text { 日現在 })^{4)}$. 同時に, 女性医師の 卒後 10 年以内のキャリアの中断が現在指摘されてお り，主な離職原因である妊娠・出産・育児に対応する ため, 女性医師が働き続けやすい環境整備の在り方が

\footnotetext{
*1 日本プライマリ・ケア連合学会 男女共同参画委員会

*2 社会医療法人清風会 岡山家庭医療センター (FPCO)/津山ファミリークリニック

*3 日本医療福祉生協連合会 家庭医療学開発センター (CFMD)/あさ抄診療所

著者連絡先：村田亜紀子 岡山家庭医療センター〔 〔 708-1323 岡山県勝田郡奈義町豊沢 292-1〕 email address : amurata-kyu@umin.ac.jp

日本プライマリ・ケア連合学会 男女共同参画委員会 HP : http : //www.primarycare-wlb.com/
} 
課題となっている ${ }^{5 / 6)}$.

この課題に対するポジティブ・アクション（積極的 是正措置) の手法の 1 つとして, 実質的な研修を受け る機会の平等の確保, 多様な価值観をもつ人々が学会 に参画する機会を確保し組織・運営の活性化を図るこ とを目的に, 学術大会・講演会等における託児所設置 が行われている. 学会総会・学術講演会での託児所の 設置は, 2008 年には 5 割程度 (大会長への一任を含 む $)^{7}$ だったが，2014 年には 7 割強に増加した ${ }^{8)}$. Web によると, 特に JPCA を除く基本領域 18 学会では,

17 学会が 2014-2015 年開催の学術大会で託児所を設 置していた（日本臨床検査医学会は設置不明）。また 大学医学部で行う講習会・研修会でも少なくとも 3 割 に設置されている ${ }^{8)}$.

学会でのポジティブ・アクション推進には男女共同 参画に関する部門の設立が有効であり, 日本医学会分 科会での男女共同参画部門（下部組織・小委員会等） 設置は, 2011 年には約 2 割強に過ぎなかった 2014 年には 5 割弱（導入予定含む）と近年 3 年間で 倍増した ${ }^{8)}$. しかし, 早期に設立されていた下部組 織・委員会であっても, 2010 年度の委員会開催回数 は 0〜4 回とばらつきがみられ9 , 活動の程度に差が あり, 活動の活性化が今後の課題である。

\section{2. プライマリ・ケア領域 3 学会合併に伴う学会 員数等推移の歴史と託児所の関わり}

JPCA は, 2010 年 4 月旧日本プライマリ・ケア学 会・旧日本家庭医療学会・旧日本総合診療医学会の 3 学会の合併により誕生した.

日本プライマリ・ケア学会は,「実地医家のための 会」の 15 周年記念事業として 1978 年 6 月に創設され た ${ }^{10)}$. 医師以外の職種も自由に参加できる学会として 発足し, 1979 年に 379 人だった会員数は 1990 年には 1900 人を越えた ${ }^{11} .1993$ 年 6 月の認定制度の設置, 2001 年 4 月の専門医認定開始を経て, 2006 年には会 員数 4300 人 (うち医師約 3800 人) ${ }^{12}$ となった.

日本総合診療医学会は, 大学に扔ける総合診療科の 新設が相次いだ 1993 年に総合診療研究会として創設 された，総合診療のあり方や役割の検討, 臨床疫学な どの方法論を積極的に取り入れた臨床研究の推進・発 表に注力し ${ }^{12)}, 2000$ 年に日本総合診療医学会となり 2001 年から英文学会誌の刊行を開始した。会員数は 2002 年には 600 人 ${ }^{13)}, 2007$ 年 6 月には 830 人であっ た ${ }^{14)}$.

日本プライマリ・ケア学会・日本総合診療医学会
は, 従来の活動に関するオフィシャルサイトが現在確 認できず学会誌も web 化されていないため, 活動実 態や託児所の開設状況の確認が困難であった。 よっ て, 過去のオフイシャルサイトが残存しており会報等 にて活動穾態の確認できた日本家庭医療学会を中心に 託児所との関連を以下に述べる。

日本家庭医療学会の前身である家庭医療学研究会 は, 1984 年全国の地域の医師や医学部の教員の有志 が集まって家庭医療学に関する勉強会が発足, 家庭医 学セミナーの開催と機関誌「家庭医」の発行を開始し たことを契機に 1986 年 11 月創設された. 当初より学 生・若手医師の育成に力が入れられており，1989 年 8 月に第 1 回となる夏期セミナーが開催 ${ }^{15)}$ されてからは 毎年夏期セミナーが開催されるようになった。

発足後しばらくは会員数が伸び恼み, 年 1 回開催さ れる家庭医療学研究会総会は 100 名規模, 夏期セミ ナーは参加者・講師を合わせて 60 名程度, 1992 年よ り開始された年 1 回の生涯教育のためのワークショッ プは 50 名弱の規模で推移した. 1999 年 8 月第 11 回 夏期セミナー終了後に学生の発案で学生部会が発足, 同年 11 月に開催された第 14 回家庭医療学研究会総会 (東京) より総会への学生の参加が増え, 規模も 140 名を超元拡大傾向となった（図 1·表 1).

2002 年 11 月第 17 回家庭医療学研究会総会終了 後, 日本家庭医療学会として正式にスタートした。総 会期間中に, 大会長亀谷学 (以下敬称略・50 音順) からの提案で「女性医師のキャリアとしての家庭医」 と題したセッションが設けられたが, このWSを きっかけに担当者だった大野毎子, 高屋敷明由美, 武 田裕子, 前野貴美, 西村真紀らにより「託児所設置の アンケート」が行われ，その結果を受けて 2003 年 11

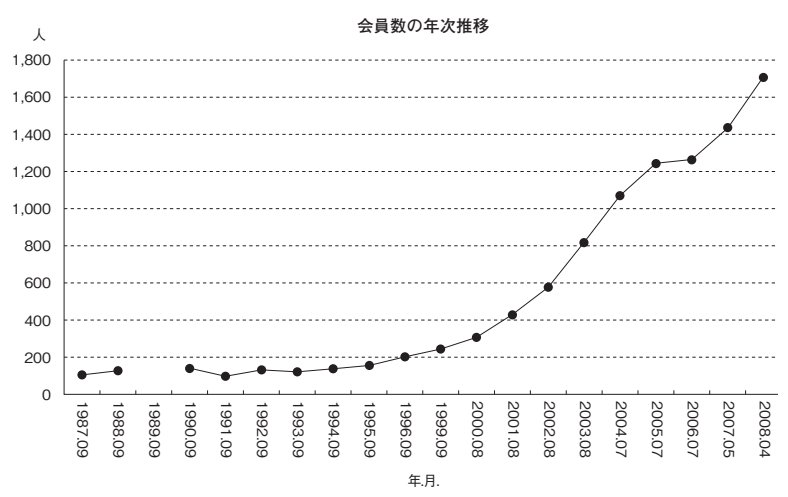

図 1 日本家庭医療学会の現況・年次推移 (1987 2008)

(学会の現況・年次推移. 日本家庭医療学会. 2008-4-30. http://plaza.umin.ac.jp/jafm/html/genkyou.html) 
表 1 旧家庭医療学会学術集会・セミナーの場所と学会員数・参加者数の推移（1998２009 年度）

\begin{tabular}{|c|c|c|c|c|c|c|c|c|c|c|c|c|c|c|c|c|c|}
\hline \multirow{3}{*}{ 年度 } & \multirow{3}{*}{$\begin{array}{l}7 \text { 月末時点の } \\
\text { 学会員数 (人) }\end{array}$} & \multicolumn{4}{|c|}{ 学術集会 } & \multicolumn{4}{|c|}{ 夏期セミナー } & \multicolumn{4}{|c|}{ 生涯教育 WS } & \multicolumn{4}{|c|}{ 冬期セミナー } \\
\hline & & \multirow{2}{*}{ 回 } & \multirow{2}{*}{ 場所 } & \multirow{2}{*}{$\begin{array}{c}\text { 参加者数 } \\
\text { (人) }\end{array}$} & \multirow{2}{*}{$\begin{array}{c}\text { 託児 } \\
\text { 利用者数 }\end{array}$} & \multirow{2}{*}{ 回 } & \multirow{2}{*}{ 場所 } & \multicolumn{2}{|c|}{ 参加者数 (人) } & \multirow{2}{*}{ 回 } & \multirow{2}{*}{ 場所 } & \multicolumn{2}{|c|}{ 参加者数 (人) } & \multirow{2}{*}{ 回 } & \multirow{2}{*}{ 場所 } & \multirow{2}{*}{$\begin{array}{c}\text { 参加者数 } \\
\text { (人) }\end{array}$} & \multirow{2}{*}{$\begin{array}{c}\text { 託児 } \\
\text { 利用者数 }\end{array}$} \\
\hline & & & & & & & & 参加者 & 講師 & & & 参加者 & 講師 & & & & \\
\hline 1998 & 196 & 13 & 東京 & 100 超 & & 10 & 札幌 & \multicolumn{2}{|c|}{64} & 7 & 名古屋 & 42 & 2 & & & & \\
\hline 1999 & 226 & 14 & 東京 & 約 150 & & 11 & 倉敷 & 35 & 26 & 8 & 名古屋 & 42 & 3 & & & & \\
\hline 2000 & 301 & 15 & 東京 & 169 & & 12 & つくば & 80 & 約 20 & 9 & 名古屋 & 92 & 3 & & & & \\
\hline 2001 & 422 & 16 & 東京 & - & & 13 & つくば & 86 & 33 & 10 & 名古屋 & 77 & 5 & & & & \\
\hline 2002 & 577 & 17 & 東京 & 約 200 & & 14 & 千葉 & 150 & 40 & 11 & 名古屋 & 84 & 5 & & & & \\
\hline 2003 & 810 & 18 & 東京 & 369 & こども 7 名 & 15 & 長野 & 156 & - & 12 & 名古屋 & \multicolumn{2}{|c|}{110} & & & & \\
\hline 2004 & 1,070 & 19 & 大宮 & 405 & - & 16 & 長野 & 191 & 59 & & & & & & & & \\
\hline 2005 & 1,240 & $20^{* 1}$ & 京都 & 2,000 超 & 不明 & 17 & 新潟 & 191 & 51 & 13 & 東京 & 152 & 12 & 1 & 東京 & 34 & 設置なし \\
\hline 2006 & 1,258 & $21^{* 2}$ & 名古屋 & 1,617 & 設置なし & 18 & 湯沢 & 186 & 50 & 14 & 大阪 & 184 & 22 & 2 & 大阪 & 83 & - \\
\hline 2007 & 1,536 & 22 & 東京 & 641 & - & 19 & 野田 & 193 & 59 & 15 & 大阪 & \multicolumn{2}{|c|}{261} & 3 & 大阪 & 72 & - \\
\hline 2008 & 1,826 & 23 & 東京 & 491 & 不明 & 20 & 新潟 & 145 & 53 & 16 & 大阪 & \multicolumn{2}{|c|}{366} & 4 & 東京 & 88 & こども 3 名 \\
\hline 2009 & 2,035 & $24^{* 3}$ & 京都 & - & - & 21 & 群馬 & \multicolumn{2}{|c|}{ (160) } & 17 & 大阪 & 3( & & 5 & 東京 & (120) & こども 4 名 \\
\hline
\end{tabular}

※ 日本家庭医療学会会報 33-70 号（1998.4-2010.2）より抜粋したデータを示す（日本家庭医療学会. http://plaza.umin.ac.jp/jafm/report/index.html）. 参加者数が分か らない場合は定員を記載し, 定員も分からない場合は欠損值としてーで表記した.

*1 日本学術会議との共同主催であり, 世界一般医・家庭医学会 2005 年アジア太平洋学術会議 (WONCA Asia Pacific Regional Conference 2005), 第 28 回日本プライ マリ・ケア学会学術集会, 第 13 回日本総合診療医学会学術集会と同時開催

*2 第 29 回日本プライマリ・ケア学会および日本総合診療医学会臨床研究インタレストグループと合同でプライマリ・ケア関連学会連合学術会議として開催

*3 第 32 回日本プライマリ. ケア学会. 第 17 回日本総合診療医学会との合同開催

月第 18 回日本家庭医療学会学術集会より大会長藤沼 康樹に一任する形で託児所が初めて開設されることに なった ${ }^{16) 17)}$.

2004 年 11 月第 19 回日本家庭医療学会学術集会で も引き続き託児所が開設された ${ }^{18)}$ 。学術集会期間中に 開かれた運営委員会にて, 運営委員会の構成を考慮 し，女性医師等からもオブザーバーとして意見聴取を 行う方針が打ち出された ${ }^{19)}$ が，実際にはオブザーバー 参加は進まなかった。

2005 年 5 月日本学術会議との共同主催で, 第 28 回 日本プライマリ・ケア学会学術集会, 第 13 回日本総 合診療医学会学術集会, 第 20 回日本家庭医療学会学 術集会, が同時開催された。こうして家庭医療への関 心が高まる中, 学会員数は 1000 名を越えた.

2006 年 2 月, 若手家庭医部会（2004 年秋有志の会 として発足）主催で第 1 回冬期セミナーが宿泊込の 1 泊 2 日の日程で開催された。この際，子連れの参加者 同士が協力してベビーシッターを別室に手配する形で 託児が行われた経緯があり，翌年以降は冬期セミナー には毎年託児所が設置されるようになった。同年 4 月 初めてとなる役員選挙にて指名理事として西村真紀が 日本家庭医療学会初の女性理事となった ${ }^{20)}$.

同年 5 月第 21 回日本家庭医療学会学術集会は第 29 回日本プライマリ・ケア学会および日本総合診療医学 会臨床研究インタレストグループと合同でプライマ リ・ケア関連学会連合学術会議として開催されたが,
諸般の事情により託児所が開設できなかった。 しか し, 2007 年 6 月第 22 回学術集会では新たに理事と なった西村真紀の協力もあり，再度託児所が設置され $た^{21)}$.

2008 年時点で会員は約 1700 人となっていた.

2009 年合併前最後となる第 24 回学術集会は, 第 32 回日本プライマリ・ケア学会・第 17 回日本総合診療 医学会との合同開催で行われ，新型インフルエンザの 流行により 5 月の予定が 8 月に急遽延期となったが, 託児所は設置された。

\section{3. 男女共同参画委員会による学術大会・各セミ ナーでの託児所充実に向けての取組み}

JPCA 学術集会・各セミナーの場所と学会員数・参 加者数・託児所利用者のべ数の推移を表 2 に示す. JPCA 誕生後, 学術大会では大会長へ一任する形での 託児所運営が続いた。 また，春季・秋季生涯教育セミ ナーでは生涯学習委員会委員長雨森正記の意向で第 2 回より，冬期セミナーでは若手医師有志により定期的 な託児所設置が継続された。 2012 年 3 月の第 7 回冬 期セミナーより，当時託児所担当スタッフだった村田 西紀子が web 調査を経て, 第 7 回冬期セミナー代表 吉田伸の協力のもと, セミナー終了後に開催される指 導医養成講習会（第 3 回）でも併せて託児所設置を, 指導医養成講習会担当理事竹村洋典の了承を得て開始 した。 
表 2 JPCA 学術集会・各セミナーの場所と学会員数・参加者数・託児所利用者のべ数の推移（2010 2014 年度）

\begin{tabular}{|c|c|c|c|c|c|c|c|c|c|c|c|c|c|c|c|c|c|c|c|c|c|}
\hline \multirow[b]{2}{*}{ 年度 } & \multirow[b]{2}{*}{$\begin{array}{l}4 \text { 月末時 } \\
\text { 点の学会 } \\
\text { 員数 (人) }\end{array}$} & \multicolumn{4}{|c|}{ 学術大会 } & \multicolumn{4}{|c|}{ 春季生涯教育セミナー } & \multicolumn{4}{|c|}{ 夏期セミナー } & \multicolumn{4}{|c|}{ 秋季生涯教育セミナー } & \multicolumn{4}{|c|}{ 冬期セミナー } \\
\hline & & 回 & 場所 & $\begin{array}{l}\text { 参加者 } \\
\text { 数 (人) }\end{array}$ & $\begin{array}{c}\text { 託児所 } \\
\text { 利用者の } \\
\text { べ数 (人) }\end{array}$ & 回 & 場所 & $\begin{array}{c}\text { 参加者数 } \\
\text { (人) }\end{array}$ & $\begin{array}{c}\text { 託児所 } \\
\text { 利用者の } \\
\text { べ数 (人) }\end{array}$ & 回 & 場所 & $\begin{array}{l}\text { 参加者 } \\
\text { 数 (人) }\end{array}$ & $\begin{array}{c}\text { 託児所 } \\
\text { 利用者の } \\
\text { べ数 (人) }\end{array}$ & 回 & 場所 & $\begin{array}{l}\text { 参加者 } \\
\text { 数 (人) }\end{array}$ & $\begin{array}{c}\text { 託児所 } \\
\text { 利用者の } \\
\text { べ数（人） }\end{array}$ & 回 & 場所 & $\begin{array}{l}\text { 参加者 } \\
\text { 数 (人) }\end{array}$ & $\begin{array}{c}\text { 託児所 } \\
\text { 利用者の } \\
\text { ベ数 (人) }\end{array}$ \\
\hline 2010 & - & 1 & 東京 & - & - & & & & & 22 & 埼玉 & 80) & 設置なし & 1 & 大阪 & $(450)$ & 設置なし & 6 & 東京 & (250) & $6^{*}$ \\
\hline 2011 & 6,406 & 2 & 札幌 & 2,242 & - & & & & & 23 & つくば & 320 & 設置なし & $\begin{array}{l}2 \\
3\end{array}$ & $\begin{array}{l}\text { 東京 } \\
\text { 大阪 }\end{array}$ & $\begin{array}{l}(750) \\
(600)\end{array}$ & $\begin{array}{l}7^{*} \\
7^{*}\end{array}$ & 7 & 東京 & 237 & 19 \\
\hline 2012 & 7,111 & 3 & 福岡 & 2,430 & 21 & 4 & 東京 & $(500)$ & $11^{*}$ & 24 & 湯河原 & $(180)$ & 設置なし & 5 & 東京 & - & 21 & 8 & 東京 & 292 & 24 \\
\hline 2013 & 8,053 & 4 & 仙台 & 2,362 & 23 & 6 & 名古屋 & （約 500） & 8 & 25 & 湯河原 & $(210)$ & 3 & 7 & 大阪 & (600) & 19 & 9 & 東京 & 269 & 23 \\
\hline 2014 & 10,984 & 5 & 岡山 & 3,885 & 39 & 8 & 札幌 & （約 500） & 8 & 26 & 湯河原 & (250) & 10 & 9 & 大阪 & 533 & 28 & 10 & 東京 & 312 & 35 \\
\hline
\end{tabular}

※1 参加者数が分からない場合は定員を括弧内に記載し，定員も分からない場合は欠損値としてーで表記した

※2 秋季生涯教育セミナーでは 1 日目と 2 日目で定員が異なったため多い方の人数を記載した.

* のべ人数が分からなかったため, こども数を記載した。

このように関係部署の協力により託児所の設置が継 続されていたが，第 4 回学術大会（仙台）では託児所 設置の準備が進まず主催者も当事者も困っていること が 2013 年 1 月末に発覚した。 そこで, JPCA 理事長 丸山泉の意向を受け，運営は従来どおり主催者が行う ものの，すでに設立されていた男女共同参画委員会 （旧女性会員支援委員会）が託児所の設置を支援する 役割を担うことになった。また，費用負担について も，主催者の運営上の負担が大きいこともあり，業者 への託児委託費の利用者負担との差額を学会本部が担 うことになった.

その後, 2013 年からは男女共同参画委員会支援下 での託児所設置を開始し, 第 8 回冬期セミナー, 第 4 回学術大会ともに設置が継続された。冬期セミナー運 営でのスタッフ負担軽減を目的に, 2014 年 2 月の第 9 回冬期セミナーより託児所業務の学会事務局への全面 的な委託が開始となった。 また, 講師側の要望を受 け, 2013 年 8 月第 25 回夏期セミナーより夏期セミ ナーにおける定期的な託児所設置を開始した.

第 5 回学術大会（岡山）では, 策定段階で大会長松 下明から託児所の充実を目指す意向を受け，2013 年 8 月に学会の規模と目指す託児所規模が同様で運用状況 の比較のできる外来小児科学会第 23 回学術集会にて 託児所視察を行った。外来小児科学会では会場が決 まった段階で実行委員会がまず託児所設置場所を選定 し，それから企画の調整を行う段取りで進めていると のことだった．視察結果と第 3 回・第 4 回学術大会で の託児所利用実績（各日 10〜15 名程度）を踏まえ， 主催者と相談し各日 20 名規模での開催を目指して託 児所設置場所を確保，託児所規模の拡大を行った。し かし，第 5 回学術大会で定員超過のため利用できない 利用希望者が出たこと, 学会員が多く利便性の高い関 東地区の開催であるため利用者数の増大が見込まれる
ことを考慮し, 第 6 回学術大会では実行委員長横谷省 治と相談し, 各日 30 名へさらに規模を拡大して対応 した，また，根強く要望の出ていた，懇親会における 託児所設置についても, 今回学会上層部・主催者の了 承を得て試行した。

現在の課題としては, 託児所利用費の適正化と安 心・効率的で利用しやすい託児所運営のための仕組み

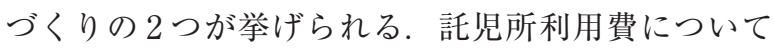
は, 業者への託児委託費の約 9 割にあたる部分の助成 と会場費を学会が担っているが, 利用者数の拡大とこ どもの低年齢化（乳児の増加）に伴い，助成総額が大 幅に増大傾向にある，無料での設置を行っている学会 も多数あることから, 男女共同参画委員会としては無 料化も含めた検討を依頼している。 しかし, JPCAの 場合約 3 割が 30 代以下と学会員構成が比較的若年で 参加者に占める託児所利用者割合が高く, 学会運営費 から捻出できる金額に限りがあることもあり，適正な 託児所利用費の検討継続に加えより効率的な託児所運 営が求められている。託児所設置の認知度は上昇して いるものの, 企画によって広報や利用者への連絡の程 度に差があり，適正運用を行うため必要な申し込み期 限や連絡先等の連絡が十分といえないものもある. よって，必要な人が必要なときに利用でき，より利用 しやすい託児所を目指して, 利用者の協力を求めつつ 活動を続ける予定である.

\section{結 語}

託児所設置は, 学会員の誰もが障壁を感じずに学術 大会・セミナー等に参加できる環境を整えることの一 環として実施されている.JPCA では学会の規模が順 調に拡大しているが，それに伴い女性会員数も上昇傾 向にある（図2）。さらに，女性会員の約 4 割が 30 代 以下とライフサイクルとして出産・育児を経験する世 


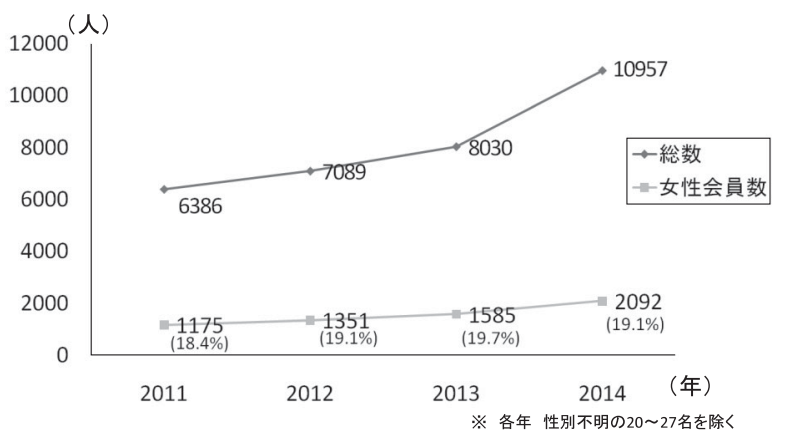

図2 2011 2014 年 4 月末時点の JPCA 女性会員 数の推移

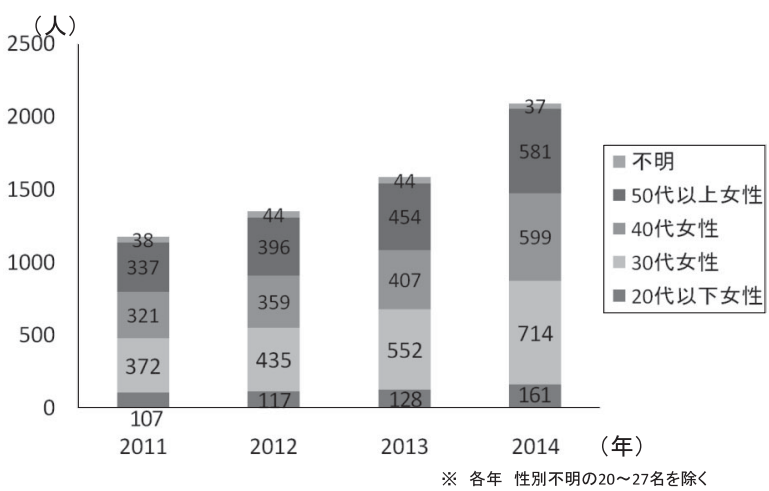

図32011 2014 年 4 月末時点の JPCA 女性会員 の年代構成

代にあたり（図 3），託児への潜在的なニーズは高い。 この数年で企画毎の託児所利用者数の飛躍的な増加が 認められ，課題はまだ多く今後も託児所のあり方につ いて検討していく必要があるだろう。

託児所は女性医師の企画参加に欠かせないものでは あるが，関係各部署の協力がなければ設置できないも のでもある. 御助力いただいたすべての方, 学会員に 感謝したい.

\section{文 献}

1）冨澤康子, 川瀬和美, 萬谷京子, 他：医学会分科会に おける女性医師支援の現状；学術集会時の学会託児所 設置状況. 日本外科学会雑誌. 2010, 111 （5）：317319.

2）家庭医療専門医の認定に関する細則. 日本プライマ リ・ケア連合学会. 2015-3-29. http://www.primarycare.or.jp/nintei/pdf/kateiiryo_saisoku.pdf, (参照 20154-29)

3）プライマリ・ケア認定医の認定に関する細則. 日本プ ライマリ・ケア連合学会. 2015-3-29. http://www. primary-care.or.jp/nintei/pdf/pc_saisoku.pdf,（参照 2015-4-29)
4) 平成 24 年医師 - 歯科医師 - 薬剂師調査の概況. 厚生 労働省. 2013-12-17. http://www.mhlw.go.jp/toukei/ saikin/hw/ishi/12/, (参照 2015-4-29)

5）文部科学省科学研究費補助金, 基盤研究 (C), 研究 成果報告書 (2006-2008)，泉美貴， 2008

6）医政局医事課：女性医師のさらなる活躍を応援する懇 談会報告書. 厚生労働省. 2015-1-23. http://www. mhlw.go.jp/stf/shingi2/0000071857.html, (参照 20154-29)

7）女性外科医支援委員会：日本医学会分科会における女 性医師支援の現況に関する調査報告書. 日本外科学 会. 2009-5-15. http://www.jssoc.or.jp/other/info/ info20090515.pdf, (参照 2015-4-29)

8）高橋克子, 秋葉則子, 鹿島直子, 他：大学医学部, 日 本医学会分科会, 医師会の男女共同参画は進んでいる か; アンケート結果から見えるもの. 日本医師会雑 誌. $2014 ; 143(6): 1232-1235$.

9）女性外科医支援委員会. 日本医学会分科会における女 性医師支援の現況に関する調査報告書. 日本外科学 会. 2012-5-15. http://www.jssoc.or.jp/other/info/ info20120516.pdf, (参照 2015-4-29)

10）矢吹清人, 箕輪良行. 日本プライマリ・ケア連合学会 のルーツのルーツ; 「実地医家のための会」誕生秘話 矢吹清人先生に聞く。日本プライマリ・ケア連合学会 誌. 2012, 35 (2), 120-124.

11）渡辺淳：日本プライマリ・ケア学会 10 年の歩みと将 来への期待(概略)。プライマリ・ケア．1988, 11 (3), $228-233$

12）津田司, 小松真, 山田隆司, 小泉俊三. 合同座談会 ; 地域医療を担う医師の育成を目指して。 月刊地域医 学. 2006, 20 (12), 1050-1060.

13）第 10 回日本総合診療医学会でのナイトセッション; 第 1 回臨床研修ニュービジョン; 総合臨床研修必修化 と総合診療. プライマリ・ケア教育連絡協議会. 2002-2-16. http://www.reference.co.jp/primarycare/activity1.pdf, (参照 2015-4-29)

14）齊藤裕之. 若手家庭医部会主催シンポジウム；これか らの家庭医療と総合診療。日本プライマリ・ケア連合 学会若手医師部会. 2007-6-23. http://www.primarycare.or.jp/wakate/sym01/, (参照 2015-4-29)

15）津田司. 少子高齢社会に適した家庭医療とは；日本家 庭医療学会の歴史を顧みながら。日本家庭医療学会. 2007-06-09. http://plaza.umin.ac.jp/jafm/fd/20070609/ 070609tsuda.pdf, (参照 2015-4-29)

16）日本家庭医療学会・学術集会における託児所設置のア ンケート結果報告, 第 18 回学術集会での託児所設置 の扮知らせ. 日本家庭医療学会. 2003-11-15/16. http:// plaza. umin.ac.jp/ jafm/autumn/18th/qnar_takuji. html, (参照 2015-4-29)

17）学術集会における託児所設置のアンケート結果報告. 日本家庭医療学会会報, 2003, $48: 19$.

18）第 19 回日本家庭医療学会学術集会・総会. 2004-11- 
6/7. 日本家庭医療学会. http://plaza.umin.ac.jp/ jafm/autumn/19th/index.html, (参照 2015-4-29)

19）日本家庭医療学会運営委員会議事録. 日本家庭医療学 会会報, 2004, 52:4-6.

20）新役員からひとこと．日本家庭医療学会会報，2006, $56: 8-11$

21）平成 19 年度第 2 回日本家庭医療学会 理事会 議事 録. 日本家庭医療学会会報, 2007, 61：15-16.

\section{“男女共同参画委員会”ホームページのご案内}

http://www.primarycare-wlb.com/

当委員会の活動履歴, お薦めの書籍, イベント 案内, 他学会などの活動, リンク集など揭載して います.ぜひご覧ください. 